І. І. Вакулик

\title{
СУЧАСНІ ВЕТЕРИНАРНО-МЕДИЧНІ ТЕРМІНИ ЯК ПРЕЗЕНТАНТИ АНАТОМІЧНОЇ НОМЕНКЛАТУРИ
}

Вакулик I. I. Сучасні ветеринарно-медичні терміни як презентанти анатомічної номенклатури.

У статті розглянуто структурну організацію сучасних анатомічних термінів, проаналізовано потенційну здатність сполучуваності термінів ветеринарномедичного спрямування та види логічних зв’язків між ними.

Ключові слова: універсальна картина світу, термінологічні стандарти, термінологічний код, анатомічна номенклатура, терміни ветеринарної медицини, монокомпонентні терміни, полікомпонентні терміни.

Вакулик И. И. Современные ветеринарно-медицинские термины как презентанты анатомической номенклатуры.

В статье рассмотрена структурная организация современных анатомических терминов, проанализирована потенциальная возможность совместимости терминов ветеринарно-медицинского направления и виды логических связей между ними.

Ключевые слова: универсальная картина мира, терминологические стандарты, терминологический код, анатомическая номенклатура, термины ветеринарной медицины, монокомпонентные и поликомпонентные термины.

Vakulyk I. I. Actual veterinary and medical terms as the representers of anatomical nomenclature.

The structural organization of anatomical terms is considered in the article; the potential compatibility quality of veterinary and medical terms and the types of logical ties between them are analyzed.

Key words: universal worldview, terminological standards, terminological code, anatomical nomenclature, veterinary medicine terms, monocomponent and polycomponent terms. 
У науковій літературі дедалі частіше порушується проблематика універсальності картин світу (мовної, концептуальної, наївної, наукової), що свідчить про багатовимірність української мови. Попри існування різних наукових шкіл, сучасний стан вивчення моделювання картини світу та спроби ії опису демонструє відкритість, відповідно, і дискусійність питання.

Термін як частина термінологічної матриці відповідної сфери знань вже давно локалізувався в галузевих словниках української мови. Нині, як зазначає А. Баранов, налічують понад двадцять тисяч термінологічних стандартів. Особливі стандарти з організації терміносистем розробляються не лише на державному рівні, яких існує понад шістсот, але й міжнародному (наприклад, міжнародні досліди в галузі термінології координує Віденський міжнародний центр інформації з термінології - Інфотерм; міжнародні організації з уніфікації термінологічних неологізмів у Варшаві, міжнародні організації зі стандартизації). Формуються термінологічні банки даних, підтримувані Технічним комітетом стандартизації, створюються комп’ютерні версії машинного перекладу. Тож у такий спосіб уніфікація наукового бачення світу набуває обертів практично-промислового значення [5, с. 739]. Ведуться також розробки термінологічних стандартів й окремими фірмами, компаніями, які встановлюють пріоритетні принципи кодифікації інформаційно-технічних терміносистем.

Актуальність заявленої в назві проблематики полягає у виявленні різнопланових моделей сучасних анатомічних термінів й порушується автором уперше.

Мета розробки полягає у презентації структури термінів ветеринарії, що увійшли до сучасного наукового обігу. Завдання автора - описати специфіку термінологічної номінації в системі анатомічної номенклатури.

Матеріалом дослідження слугували двомовні словники, енциклопедії, довідники та наукова фахова література ветеринарної медицини. Усі приклади номенів «двослівні» / «двочленні», «трислівні» / «тричленні» тощо повинні сприйматися як синонімічні. Терміни наводяться за схемою: латинський анатомічний термін - український відповідник - англійський термін.

Nomina anatomica veterinaria, укладена за системним принципом будови організму тварини, є науково обгрунтованим та уніфікованим перекладом анатомічних термінів, які використовуюються у ветеринарній медицині, порівняльній морфології та біології [1, с. 5].

Традиційно анатомічні терміни за кількістю компонентів поділяються на однослівні, двослівні, трислівні еtс.

Однослівні терміни виражаються переважно іменником у формі називного відмінка однини або множини: caput, itis $n$ (Nom. Sing.) - голова; tendo, inis $m$ (Nom. Sing.) - сухожилок; тиsculus, i m (Nom. Sing.) - м'яз; vertebra, aе (Nom. Sing.) - хребець; costae, arum (Nom. Plur.) - ребра.

До цієї категорії належать терміни, що стосуються частин і ділянок ๑ І. І. Вакулик, 2013. 
тіла: cарит - голова - head, cranium - череn - skull, facies - лице (морда) face, collum (cervix) - иия (ииика) - neck, truncus - тулуб - trunk, abdomen живіт (черево) - abdomen, pelvis - mаз - pelvis, cauda - xвicm - tail. Однослівні анатомічні терміни можуть презентувати прикметники, які вказують на розташування i напрямок частин тіла: transversalis nоперечний - transverse, medialis - медіальний (присередній) - теdial, intermedius - проміжний - intermediate, anterior - передній - anterior, posterior - задній - posterior, internus - внутрішній - internal, externus зовнішній - external, dexter - правий - right, sinister - лівий - left, transverses nоперечний - transverse, longitudinalis - повздовжній - longitudinal, superficialis - поверхневий - superficial, profundus - глибокий-deер, або які відносяться до кінцівок: palmaris - nальмарний (долонний) - palmar (volar), plantaris - плантарний (підошовний) - plantar.

У науковій літературі termini ad membra spectantes подано в перекладі: proximalis - найближчий, distalis - віддалений, cranialis черепний, caudalis - хвостовий, medialis - присередній, dorsalis - спинний, cпинковий, ventralis - черевний, medianus - серединний. Щодо терміна dorsalis «спинний, той, що знаходиться на спині» < dorsum, $i \mathrm{n}$ «сnuна» (подекуди перекладається як «спинка»), прикметник може перекладатися як «спинковий». Цей термін стосується дорсальної частини хвоста, тулуба, шиї, поверхні голови (dorsum nasi-cпика носа, dorsum linguаe - спинка язика, dorsum тапиs - спинка кисті, dorsum pedis - спинка стопи). Терміни cranialis - черепний та caudalis - хвостовий використовуються на позначення утворів шиї, тулуба, хвоста, кінцівок; lateralis - бічний уживають стосовно всього тіла (виняток становлять axialis - ocьовий, abaxialis - неосьовий, що позначають сторони пальців у свійських ссавців, крім коней).

Монокомпонентні терміни поділяються на прості, похідні або складні.

Прості можуть бути виражені одним словом: skeleton - cкелет skeleton, feтur - cтегно - thigt, pes - cmona - foot, crus - гомілка - leg, gепи - коліно - knеe, antebrachium - передпліччя - forearm. Прості монокомпонентні бувають похідними, які утворилися додаванням префіксів чи суфіксів до кореня іменника (alveolus - альвеола, комірка < alveus, i mжолоб, чан, корито; granulum - зернятко < granum, i $n$-зерно; fonticulus джерельцее, тім'ячко < fons, fontis $m$ - джерело; tubulus - трубочка < tuba, aе $f$ - труба; ерigastrium - надчеревна область < гр. ері- перебування над, gaster - шлунок; еndocardium - ендокард, внутрішня оболонка серця < endo-ycepeдині та cardia, aе $f$-серцее, вхід илуночка). Особливо багато в анатомічній номенклатурі прикметників, утворених за допомогою суфіксів -al-, -ar-, -os- (fibrosus - волокнистий < fibra, ae $f$ - волокно; caudatus хвостатий < cauda, aе $f$-хвіст; cerebralis - мозковий $<$ cerebrum, $i$ nмозок; scapularis - лопатковий < scapula, ae $f$ - лопатка; muscularis м'язовий < musculus, i $m-$ м'яз; costalis - pеберний < costa, ae $f$-ребро). 
Складні одночленні терміни утворюються сполученням основ. У таких термінах роль асимантеми виконують сполучні голосні $\boldsymbol{o}$ або $\boldsymbol{i}$ (так звані «інтерфікси»), завдяки яким поєднуються твірні основи композитів: nasolacrimalis - носослізний, huтеró ulnaris - плечоліктьовий, cипепavicularis клиночовноподібний, scaphoideus - човноподібний, сипеiformis - клиноподібний, pisiformis - грушоподіб̈ий. Основи грецьких слів поєднуються за допомогою сполучного о, наприклад: sphenoethmoidalis - клиноpeшітчастий, teтроrohyoidea - висково-підязиковий, ischiofemoralis сідничо-стегновий, spinothalamicus - спинномозково-зоровогорбовий.

Цій категорії протиставляються терміни, складова яких налічує два і більше компонентів. Тому в термінологічній системі бажано виокремлювати монокопонентні терміни та полікомпонентні, які вступають у гіперо-гіпонімічні відношення і $є$ результатом кількісного членування їх структури.

Полікомпонентні анатомічні терміни утворюються за певними моделями, елементами яких є:

Ядро (Я) - основний компонент терміна, виражений іменником у формі називного відмінка (Nom. Sing./ Plur.)

Означення узгоджене $(O y)$ - прикметник (дієприкметник, порядковий числівник), узгоджений з іменником у роді, числі та відмінку.

Означення неузгоджене (Онеу) - іменник у формі родового відмінка (Gen. Sing./ Plur.).

Прикладка (Пр) - іменник у формі називного відмінка (Nom. Sing./ Plur.). При перекладі даної категорії термінів слід дотримуватись таких правил:

- узгоджене означення перекладається перед означуваним словом;

- неузгоджене означення перекладається після означуваного слова;

- iз двох означень - узгодженого i неузгодженого - першим перекладається узгоджене означення.

Тобто іменник, який виступає загальною назвою анатомічного утворення, завжди стоїть на першому місці; прикметник, який виступає в ролі означення, конкретизує означуване слово, стоїть на другому місці. Наприклад: ligamentum transversum - поперечна зв'язка; spatium intercostale - міжреберний простір.

Двочленні анатомічні терміни можуть бути виражені узгодженим або неузгодженим означенням. Узгоджене означення виражається прикметником, дієприкметником, займенником, числівником, наприклад: mиsculus rectus - прямий м'яз; sutura lambdoidea - ламбдоподібний шов; ligamentum flavum - жовта зв'язка; ventriculus tertius - третій шлуночок; costa vera - справжнє ребро; осиlus dexter - праве око.

Неузгоджене означення перекладається українською мовою прикметником або іменником у родовому відмінку, наприклад: columna vertebrarum - хребетний стовп (стовп хребців); саvит паsi - носова ๑ І. І. Вакулик, 2013. 
порожнина (порожнина носа); angulus costae - кут ребра; crista tuberculiгребінь горбка; facies cerebri - поверхня мозку; або прикладкою (при поєднанні двох іменників у Nom. Sing.), наприклад: musculus tensor м'яз-напружувач; тиsculus levator - м'яз-підіймач.

Якщо до іменника належать узгоджене та неузгоджене означення, то в анатомічних і гістологічних термінах узгоджене означення стоїть на першому місці, а неузгоджене - на другому, наприклад: facies costalis scapulae - реберна поверхня лопатки; тusculus latissimus dorsi найшириий м'яз спини; vena coronaria ventriculi - коронарна вена шлунка; tunica fibrosa bulbi - волокниста оболонка очного яблука.

у багатьох термінах неузгоджене означення вживається у препозиції, порівняйте: cavitas oris propria - власна ротова порожнина; lamina dentis medialis - присередня зубна пластинка.

Якщо іменник має кілька означень, то на першому місці ставиться найважливіше 3 них, яке найбільш яскраво і чітко вирізняє дане поняття серед інших однорідних, наприклад: systema nervosum periphericum периферійна нервова система. Прикметники, що позначають простір (правий, лівий, бічний, передній, задній, верхній, нижній тощо); форму (круглий, овальний, квадратний, кубічний); величину (великий, малий); колір (чорний, червоний, жовтий), ставляться на останньому місці. При перекладі таких термінів українською мовою порядок слів - зворотний, наприклад: arteria gastrica dextra - права шлункова артерія; arteria gastrica sinistra - ліва шлункова артерія; arteria pulmonalis dextra - права легенева артерія; processus articularis superior - верхній суглобовий відросток; теdulla ossium flava - жовтий кістковий мозок; арегtига pelvis inferior - нижній отвір таза.

До складу багаточленних термінів можуть входити два іменники, кожний зі своїм означенням, наприклад: facies articularis ossis temporalis суглобова поверхня вискової кістки; lamina medialis processus pterygoidei присередня пластинка крилоподібного відростка $[7 ; 1 ; 2 ; 4]$.

У таблиці розглянемо структуру полікомпонентних термінів, систематизувавши порядок їх перекладу українською мовою.

\begin{tabular}{|c|c|c|}
\hline Структура терміна & $\begin{array}{c}\text { Модель, порядок } \\
\text { перекладу (Пп) }\end{array}$ & Приклади \\
\hline $\begin{array}{cc}\text { a) іменник (Nom.) + прикметник (Nom.) } \\
1\end{array}$ & $\begin{array}{r}\text { Я + Oy } \\
\text { Пп.: } 21 \\
\end{array}$ & $\begin{array}{l}\text { tunica mucosa - слизова оболонка } \\
\text { oculus dexter - праве око }\end{array}$ \\
\hline $\begin{array}{c}\text { b) іменник (Nom.) + іменник (Gen.) } \\
1\end{array}$ & $\begin{array}{r}\text { Я + Онеу } \\
\text { Пп.: } 12 *\end{array}$ & $\begin{array}{l}\text { corpus vertebrae - тіло хребия } \\
\text { *У деяких випадках неузгоджене } \\
\text { означення може перекладатися } \\
\text { відповідним прикметником: } \\
\text { cavum nasi - порожнина носа / } \\
\text { носова порожнина } \\
\text { arcus costarum - реберна дужка }\end{array}$ \\
\hline $\begin{array}{c}\text { c) іменник (Nom.) + іменник (Nom.) } \\
1\end{array}$ & $\begin{array}{l}\text { Я }+ \text { Пр } \\
\text { Пп.: } 12\end{array}$ & musculus flexor -м'яз-згинач \\
\hline
\end{tabular}




\begin{tabular}{|c|c|c|}
\hline \multicolumn{3}{|c|}{ Трислівні } \\
\hline Структура терміна & $\begin{array}{r}\text { Модель, } \\
\text { Пп } \\
\end{array}$ & Приклади \\
\hline $\begin{array}{ccc}\text { a) імен. (Nom.) }+ \text { прикм. (Nom.) }+ \text { прикм.(Nom.) } \\
1 & 2 & 3\end{array}$ & $\begin{array}{r}\boldsymbol{Я}+\mathbf{O y}+\mathbf{O y} \\
\text { Пп.: } 321\end{array}$ & $\begin{array}{l}\text { arteria coronaria dextra - права } \\
\text { вінцева артерія } \\
\text { crista оссіріtalis externa - } \\
\text { зовнішиніи потиличний гребінь }\end{array}$ \\
\hline $\begin{array}{c}\text { b) імен. (Nom.) + імен. (Gen.) + імен. (Gen.) } \\
1 \\
2\end{array}$ & $\begin{array}{c}\text { Я+Онеу+Онеу } \\
\text { Пп.: } 123\end{array}$ & $\begin{array}{l}\text { crista colli costae - гребінь } \\
\text { шийки ребра } \\
\text { articulatio capitis costae - } \\
\text { суглоб головки ребра }\end{array}$ \\
\hline $\begin{array}{ccc}\text { c) імен. (Nom.) + прикм. (Nom.) + імен. (Gen.) } \\
1\end{array}$ & $\begin{array}{c}\text { Я + Оу + Онеу } \\
\text { Пп.: } 213\end{array}$ & $\begin{array}{l}\text { tunica mucosa nasi - слизова } \\
\text { оболонка носа } \\
\text { musculus longus colli - довгий } \\
\text { м'яз ший }\end{array}$ \\
\hline $\begin{array}{ccc}\text { d) імен. (Nom.) + імен. (Gen.) + прикм. (Nom.) } \\
1 & 2 & 3\end{array}$ & $\begin{array}{l}\text { Я + Онеу + Оу } \\
\text { Пп.: } 312\end{array}$ & $\begin{array}{l}\text { fossa cranii media - середня } \\
\text { ямка черепа } \\
\text { lobus hepatis dexter - права } \\
\text { частка печінки }\end{array}$ \\
\hline $\begin{array}{ccc}\text { e) імен. (Nom.) + імен. (Gen.) + прикм. (Gen.) } \\
1 & 2 & 3\end{array}$ & $\begin{array}{c}\text { Я + Онеу + Оу } \\
\text { Пп.: } 132\end{array}$ & $\begin{array}{l}\text { spina scapulae dextrae - ocmь } \\
\text { nравої лопатки } \\
\text { stratum nervi optici - шар } \\
\text { зорового нерва } \\
\end{array}$ \\
\hline
\end{tabular}

Терміни, які складаються 3 чотирьох і більше слів, являють собою різні комбінації зазначених моделей [3]. Наприклад:

а) імен. (Nom.) + прикм. (Nom.) + прикм. (Nom.) + прикм. (Nom.)

$$
\begin{array}{llll}
2 & 3 & 4
\end{array}
$$

Модель: Я + Oy + Oy + Oy

Порядок перекладу: 4321

arteria temporalis profunda caudalis - каудальна глибока вискова артерія

b) імен. (Nom.) + прикм. (Nom.) + імен. (Gen.) + імен. (Gen.)

$$
12 \quad 3 \quad 4
$$

Модель: Я + Оу + Онеу + Онеу

Порядок перекладу: 2134

facies articularis tuberculi costae - суглобова поверхня горбка ребра

c) імен. (Nom.) + прикм. (Nom.) + імен. (Gen.) + прикм.(Nom.)

$$
\begin{array}{llll}
1 & 2 & 3 & 4
\end{array}
$$

Модель: Я + Оу + Онеу + Оу

Порядок перекладу: 4213

musculus obliquus capitis cranialis - краніальний косий м'яз голови

d) імен. (Nom.) + прикм. (Nom.) + імен. (Gen.) + прикм. (Gen.)

$$
1234
$$

Модель: Я + Оу + Онеу + Оу

Порядок перекладу: 2143

tunica mucosa vesicae felleae - слизова оболонка жовчного міхура

е) імен. (Nom.) + імен. (Gen.) + прикм.(Nom.) + прикм.(Nom.).

1

2

3 
Модель: Я + Онеу + Оу + Оу

Порядок перекладу: 4312

lobus hepatis dexter medialis - медіальна права частка печінки

f) імен. (Nom.) + імен. (Nom.) + імен. (Gen.) + прикм.(Nom.).

$1 \quad 2 \quad 3 \quad 4$

Модель: Я + Пр + Онеу + Оу

Порядок перекладу: 1421

musculus flexor digitorum profundus - м'яз глибокий згинач пальијів [3].

Як бачимо, у термінологічних сполуках залежні компоненти виконують роль інформативного важеля: cavum abdominis - порожнина черевна, салит articulare - порожнина суглобова, саvит medullare - порожнина мозкова; dentes acиstici - зубчики слухові, dentes permanentes - зуби постійні, dentes canini - зуби ікла еtс. При залученні нового сегмента або при пропущенні якогось члена понятійне навантаження терміна може змінюватися [6, с. 172].

Серед двочленних терміносполучень виділяють дві моделі: $\mathrm{A}+\mathrm{N}$, $\mathrm{N}+\mathrm{N}$. Основим елементом при їх утворенні виступає іменник. Тричленні моделі сучасних анатомічних термінів мають відповідно структури $\mathrm{A}+\mathrm{A}+\mathrm{N}, \mathrm{A}+\mathrm{N}+\mathrm{N}, \mathrm{N}+\mathrm{A}+\mathrm{N}, \mathrm{N}+\mathrm{N}+\mathrm{N}$. Для утворення подібних структур слово, як і окреме словосполучення, можуть бути головними. $3 \mathrm{i}$ збільшенням кількості компонентів у структурі термінів збільшується i можливість різноманітних комбінацій застосування їх у ветеринарній медицині. Полікомпонентні терміни, до складу яких входять чотири i більше слів, а також терміни вищого рангу творяться на основі словосполучень нижчої структури.

Отже, презентантам анатомічної номенклатури притаманні риси: а) мають специфічні умови використання, однак належать до активних сфер спілкування в колі фахівців аналізованої галузі; б) стилістично нейтральні одиниці з високим синтагматичним потенціалом; в) характеризуються відкритістю до поповнення новими членами, відповідно, здатністю розвиватися; г) в атрибутивних конструкціях між опорним і залежним терміном виникають семантико-синтаксичні відношення.

Надалі варто здійснити аналіз семантико-синтаксичної сполучуваності термінів ботанічної та зоологічної номенклатур задля виявлення закономірностей та логічних зв'язків між дефініціями термінів. Висвітлення даної проблематики потребує комплексного дослідження, тому стане предметом подальшої наукової розвідки.

\section{Література}

1. Nomina anatomica veterinaria / [В. Т. Хомич, В. С. Левчук, Л. П. Горальський, Ю. С. Ших, І. Г. Калиновська]. - Житомир : Полісся, 2005. - 388 с.

2. Балалаєва О. Ю. Латинсько-українсько-російсько-англійський словник ветеринарно-медичних термінів : [у 2 т.] / О. Ю. Балалаєва, І. І. Вакулик. - [3-е вид., доп.]. - К. : Фітосоціоцентр, 2013. - 348 с. 
3. Балалаєва О. Ю. Електронний латинсько-український словник ветеринарномедичних термінів / О. Ю. Балалаєва . - К. : ABBY Software, 2013 (на DVD-носіï).

4. Вакулик I. I. Латинсько-українсько-російсько-англійський словник ветеринарномедичних термінів / I. І. Вакулик, О. Ю. Балалалєва, С. П. Гриценко. - . : Фітосоціоцентр , 2011. - 680 с.

5. Лінгвістична енциклопедія / [авт.-уклад. Селіванова О. О.]. - Полтава : Довкілля-К, 2010. - 844 с.

6. Панько Т. I. Українське термінознавство : [підручник] / Т. І. Панько., I. М. Кочан, Г. П. Мацюк. - Львів : Світ, 1994. - 216 с.

7. Словник морфологічних ветеринарних термінів / [Левчук В. С., Очкуренко О. М., Федотов О. В., Нетлюх М. А. ]. - К. : Вища школа, 1990. - 304 с. 